\title{
Sporcuların Antrenörlerinden Algıladıkları Etik Dışı Davranış Algısına Göre Saldırganlık ve Öfke Davranışlarının İncelenmesi
}

ISSN: 2536-5339

\author{
Burcu GÜVENDi ${ }^{1 *}$ (i) Burçak KESKIN ${ }^{1}$ (ID \\ ${ }^{1}$ Yalova Üniversitesi, Spor Bilimleri Fakültesi, YALOVA
}

DOI: 10.31680/gaunjss.718565

Orijinal Makale / Original Article

Geliş Tarihi / Received: 11.04.2020

Öz

Bu çalışmanın amacı sporcuların antrenörlerinden algıladıkları etik dışı davranış algısına göre saldırganlık ve öfke davranışları incelenerek bir takım bağımsız değişkenlere göre farklılaşıp farklılaşmadığını araştırmaktır. Araştırmada veri toplama aracı olarak Maxwell ve Moores (2007) tarafından geliştirilen, Gürbüz, Kural ve Özbek (2019) tarafından Türkçeye uyarlanarak geçerlik güvenirlik çalışması yapılan Sporda saldırganlık ve öfke ölçeği, Güven ve Öncü (2012) tarafından geliştirilen Antrenörün Etik Dışı Davranışları ile İlgili Sporcu Algısı ölçeği kullanılmıştır. Verilerin analizinde ise betimsel istatistikler, $t$ testi, tek yönlü varyans analizi (ANOVA), Tukey çoklu karşılaştırma, Pearson korelasyon testleri kullanılmıştır. Elde edilen bulgularsonucunda saldırganlık ve öfke boyutu ile antrenörlerin etik dışı davranış algısı ile ilgili sporcu algısı ölçeği toplam puanı arasında pozitif yönde düşük düzeyde anlamlı ilişki olduğu tespit edilmiştir. Millilik durumlarına göre anlamlı farklılık görülmemiştir. Saldırganlık alt boyutu cinsiyete göre anlamlı farklılık görülmezken, erkek sporcuların öfke düzeylerinin daha yüksek olduğu belirlenmiştir. Antrenörlerin etik dışı davranış algısı ile ilgili sporcu algısı ölçeği toplam puanında ise cinsiyete göre anlamlı farklılık saptanmamıştır. Takım sporcularının saldırganlık ve öfke puanlarının ve antrenörlerin etik dışı davranış algısı ile ilgili sporcu algısı ölçeği toplam puanının daha yüksek olduğu saptanmıştır. Tecrübesiz sporcuların saldırganlık düzeyleri daha yüksektir. Ayrıca yaşça büyük sporcuların antrenörlerinden algıladıkları etik dışı davranış algısı yaşça küçük sporculara göre daha fazladır. Sonuç olarak, sporcuların algıladıkları etik dışı davranış algısı arttıkça saldırganlık eylemlerinin ve öfke hislerinin arttığı söylenebilir.

Anahtar Kelimeler: Antrenör, etik, saldırganlık, öfke

\section{Examination of Competitive Aggressionand Anger Behaviors According to the Perception of Unethical Behavior of Athletes From Their Coaches}

\begin{abstract}
The goal of this study is to investigate whether athletes vary byan alyzing competitiv eaggression and anger behaviors according to the perception of unethical behaviors they experience from their coaches accordingto some independent variables. In the study, "Competitive aggressiveness and anger scale" developed by Maxwell ve Moores (2007), the validity and reliabilty study was conductud by adaptingTurkish by Gürbüz, Kural and Özbek (2019) and the "Athlete perception scale about coaches' unethical behaviors" developed by Güven and Öncü (2012) are used as data collection tool. Descriptive statistics, $t$ test, one-way variance analysis (ANOVA), Tukey multiple comparison, Pearson correlation tests were used in the analysis of the data. According to the findings, it was determined that there was a positive and low level of relationship between aggression and anger size and the total score of the coaches' perception of unethical behavior and perceived athlete perception scale. There were no significant differences in nationality. While the lower size of aggression did not differ significantly in gender, the anger levels of male athletes werefound to be higher. The total score of the athletes' perception of unethical behaviorwas not significantly different according to gender. It was found that the total score of Team athletes' aggression and anger scores and the athlete perception scalerelated to the coaches' perception of unethical behavior were higher. In experienced athletes have higher levels of aggression. In addition, older athletes' perception of unethical behavior from their coaches is higher than that of younger athletes. As a result, as the perception of unethical behavior by athletes increases, it can be said that acts of aggression and feelings of anger are scaled up as well.
\end{abstract}

Keywords: Coach, ethic, aggression, anger

\footnotetext{
* Sorumlu Yazar: Burcu GÜVENDİ
}

E-mail: burcuguvendi@gmail.com 


\section{Giriş}

Günümüzde antrenörlük mesleği içinde yaşanan etik dışı davranışlar antrenörlüğün ve sporun saygınlığını azaltmaktadır. Sporun temel taşı olan antrenörler sporun eğitici kadrosu içinde yer alan ve sporun gelişmesinde oldukça önemli role sahip olan eğiticilerdir (Dolaşır, 2006). Spor ortamında bu denli önemli bir role sahip olan antrenör, sporcularının antrenman esnasında, müsabaka da ve sonrasında veya galibiyet ve yenilgi durumunda neler hissettiğini bilmeli ve sporcusunun yerine kendini koyabilmelidir (Karakoç ve ark., 2011). Antrenörlerin ortaya koyacağı davranışların insani boyutta kabul gören değerlere sahip olması gereklidir. Başka bir ifadeyle, tüm meslekler de olduğu gibi antrenörlük de evrensel değerler temelinde mesleki etik kurallara sahip olması beklenmektedir (DolaşırTuncel ve Büyüköztürk, 2009). Antrenörlerin bazı olumsuz davranışları sporcunun memnuniyet düzeyini düşürerek, eğlence faktörünü azaltarak ve sporcunun hayal kırıklığı yaşamasına neden olarak sporu bırakmasına yol açabilir. Ayrıca başarısızıı korkusunun ortaya çıkmasına sebep olarak, sporcunun risk almasını engelleyebilir ve sporcunun kaygı düzeyini yükselterek hata yapma oranını yükseltebilir. İstenmeyen pek çok davranış öfke duygusu ile disiplin problemlerinin ortaya çıkmasına neden olabilir (Albrecht, 2003).

Öfke hissi doğal bir sezgi olmasına rağmen, öfke duygusunun kontrol altına alınamaması, saldırganlığa neden olabilmektedir. İşte bu sebepten öfke ve saldırganlık arasındaki ilişki yüksektir (Tuna, 2012). Saldırganlık ise, her zaman galip gelmek, kişileri yönetmek; işi bozmak, düşmanca, kırıcı, zorlayıcı davranış şekli olarak tanımlanmaktadır. Bir amaca yönelik saldırganca davranışlarbir kişiye, gruba ya da topluma yönelik olabilmektedir (Tiryaki, 2000). Literatüre bakıldığında sporu mücadeleci saldırgan bir oyun olduğu, tabiatı gereği içinde şiddet barındırdığı ifade edilmiş ve spor esnasında kurallı sert temasların şiddet içerikli olarak yansıtılmaması gerektiği ifade edilmiştir (Karagün ve Çağlayan, 2014). Sporda saldırganlığın azaltılması için saldırganlığın kökenlerinin bilinmesi ve antrenörlerin ve sporcuların sorumluluk almaları gerekmektedir (Doğan, 2005). Ancak sporun amacı dışında, etik ilkeleri ve ahlaki davranışları yansıtmayan; sporda yer alan saldırgan ve öfkeli hareketler, ülkemiz içinde önemli bir sorunu haline gelmiştir. Özellikle sporcuların her türlü gelişiminden sorumlu olan antrenörlerin sporcularını müsabaka öncesinde, sırasında ve sonrasında sporun etik ilkelerine uygun olarak motive etmesi gerekmektedir. Aksi yapılan durumlarda kazanma odaklı hırslar hem sporcunun 
kariyerine zarar verebilir hem de sporun saygınığını azaltabilir. Bu bağlamda araştırmanın amacı, sporcuların antrenörlerinden algıladıkları etik dışı davranış algısına göre saldırganlık ve öfke davranışları incelenerek bazı bağımsız değişkenlere göre farklarını araştırmaktır.

\section{Yöntem}

\section{Araştırmanın Modeli}

Araştırmada geçmişte ya da halen var olan bir durumu var olduğu şekliyle betimlemeyi amaçlayan tarama modellerinden ilişkisel tarama modeli kullanılmıştır. İlişkisel tarama modeli, iki veya daha çok değişken arasında birlikte değişim varlığını veya derecesini belirlemeyi amaçlayan modellerdir (Karasar, 2012).

\section{Evren ve Örneklem}

Araştırmanın evrenin tüm spor branşlarında yer alan sporcular oluştururken örneklemini ise; tesadüfi örnekleme yöntemi ile seçilen futbol, basketbol, voleybol, kick boks, güreş, taekwondo, eskrim branşlarında farkıı illerde spor yapan yaş ort.= $20,02 \pm 7,26$ olan, ort. $=8,90 \pm 6,919$ spor yılına sahip 56 kadın, 126 erkek olmak üzere toplamda 182 sporcu oluşturmaktadır.

Tablo 1. Katılımcılara Ait Demografik Değişkenler

\begin{tabular}{cccc}
\hline & & $n$ & $\%$ \\
\hline \multirow{2}{*}{ Cinsiyet } & Kadın & 56 & 30,8 \\
& Erkek & 126 & 69,2 \\
\hline \multirow{2}{*}{ Millilik } & Evet & 66 & 36,3 \\
& Hayır & 116 & 63,7 \\
\hline \multirow{2}{*}{ Branş } & Takım & 78 & 42,9 \\
& Bireysel & 104 & 57,1 \\
\hline \multirow{2}{*}{ Yaş } & $15-17$ yaş & 109 & 59,9 \\
& 18 Yaş ve Üzeri & 73 & 40,1 \\
\hline \multirow{2}{*}{ Spor Yılı } & $1-5$ Yıl & 72 & 39,6 \\
& 6-10 Yıl & 62 & 34,1 \\
& 11 Yıl ve Üzeri & 48 & 26,4 \\
\hline
\end{tabular}

\section{Veri Toplama Araçları}

Araştırmada veri toplama aracı olarak; sporda saldırganlık ve öfke ölçeği ile antrenörün etik dışı davranışları ile ilgili sporcu algısı ölçeği kullanıımıştır;

Sporda Saldırganlık ve Öfke Ölçeği: Maxwell ve Moores (2007) tarafından geliştirilen sporda saldırganlık ve öfke ölçeğinin Türkçeye uyarlaması Gürbüz, Kural ve Özbek (2019) tarafından yapılmıştır. Sporcuların müsabaka sırasındaki öfke ve 
saldırganlık düzeylerini belirlenmesi için geçerli ve güvenilir bir ölçek olan sporda saldırganlık ve öfke ölçeği 12 maddelik ve "saldırganlık" ve "öfke" olmak üzere iki alt boyuttan oluşmaktadır.Ölçek, Kesinlikle katılmıyorum (1), Tamamen Katılıyorum (5) olacak şekilde ifade edilen 5'li Likertskalası şeklinden puanlanmaktadır.

Antrenörün Etik Dışı Davranışları ile İlgili Sporcu Algısı Ölçeği: Güven ve Öncü (2012) tarafından geliştirilen ölçek 19 madde ve antrenör-sporcu ilişkisi boyutu, sportmenlik boyutu ve kişilik özellikleri boyutu olmak üzere üç faktörden oluşmaktadır. Ölçek ayrıca tek faktörlüdür ve ölçeğin, üç faktörlü olarak kullanılmasının yanı sıra tek faktörlü de kullanılması uygun görülmektedir. Tamamen Katılıyorum (5), Hiç Katılmıyorum (1) olacak şekilde ifade edilen 5'li Likert Skalası tipindedir (Güven ve Öncü, 2012).

\section{Verilerin Analizi}

Araştırmada veri analizinde SPSS 20 paket programı kullanılmış olup çalışma verilerinin dağıımını belirlemek için Kolmogorov-Smirnov testi uygulanmıştır. Kolmogorov-Smirnov testi sonucu dağılımının normal dağılıma uygun olduğu belirlenmiştir. Araştırmada istatistiki yöntemde ise; betimsel istatistikler (frekans, aritmetik ortalama, standart sapma); t testi, tek yönlü varyans analizi (ANOVA), Bonferroni çoklu karşılaştırma ve Pearson korelasyon testlerinden yararlanılmıştır.

\section{Bulgular}

Sporcuların antrenörlerinden algıladıkları etik dışı davranış algısına göre saldırganlık ve öfke davranışları incelenerek bazı bağımsız değişkenlere göre farklılaşıp farklılaşmadığını araşıımak amacıyla yapılan çalışmanın bulguları aşağıdaki gibidir.

Tablo 2. Ölçeklere Ait Ortalama Değerleri

\begin{tabular}{cccc}
\hline \multicolumn{2}{c}{ Ölçekler } & $\mathrm{N}$ & Ort. \pm Std. Sp. \\
\hline \multirow{2}{*}{ Sporda Saldırganlık ve Öfke Ölçeği } & Saldırganlık & 182 & $2,76 \pm, 867$ \\
& Öfke & 182 & $2,04 \pm, 688$ \\
\hline Antrenörlerin Etik Dışı Davranış & \multirow{2}{*}{ Etik toplam } & 182 & $1,60 \pm, 718$ \\
Algısı İle Illgili Sporcu Algısı Ölçeği & \multicolumn{2}{c}{ Tablo 2 de ortalama değerlere bakıldığında katılımcıların sporda saldırganlık }
\end{tabular}

boyutunda kararsızlık yaşadıkları ancak öfke boyutuna katılmadıkları görülmüştür. Ayrıca katıımcıların antrenörlerinden etik dışı davranış algısına da katılmadıkları belirlenmiştir. 
Güvendi B, Keskin B. (2020). Sporcuların Antrenörlerinden Algıladıkları Etik Dışı Davranış Algısına Göre Saldırganlık ve Öfke Davranışlarının İncelenmesi. Gaziantep Üniversitesi Spor Bilimleri Dergisi, 5(2), 134-145.

Tablo 3. Sporda Saldırganlık ve Öfke Ölçeği İle Antrenörlerin Etik Dışı Davranış Algısı ile İlgili Sporcu Algısı Ölçeği Korelasyon Analizi

\begin{tabular}{|c|c|c|c|}
\hline \multicolumn{3}{|c|}{ Ölçekler } & $\begin{array}{c}\text { Antrenörlerin etik dışı davranış algısı ile ilgili sporcu } \\
\text { algısı toplam puan }\end{array}$ \\
\hline \multirow{2}{*}{$\begin{array}{l}\text { Sporda Saldırganlık ve } \\
\text { Öfke Ölçeği }\end{array}$} & Saldırganlık & $\begin{array}{l}r \\
p \\
N\end{array}$ & $\begin{array}{l}209^{*} \\
, 005 \\
182 \\
\end{array}$ \\
\hline & Öfke & $\begin{array}{l}\mathrm{r} \\
\mathrm{p} \\
\mathrm{N}\end{array}$ & $\begin{array}{l}, 171^{*} \\
, 021 \\
182\end{array}$ \\
\hline
\end{tabular}

Tablo 3 de yer alan korelasyon analizine göre sporda saldırganlık ve öfke ölçeği saldırganlık ve öfke alt boyutu ile antrenörlerin etik dışı davranış algısı ile ilgili sporcu algısı ölçeği toplam puanı arasında pozitif yönde düşük düzeyde anlamlı ilişki olduğu tespit edilmiştir.

Tablo 4. Cinsiyete Göre Sporda Saldırganlık ve Öfke Ölçeği İle Antrenörlerin Etik Dışı Davranış Algısı ile Illgili Sporcu Algısı Öıçeği t-Testi Analizi

\begin{tabular}{|c|c|c|c|c|c|c|}
\hline Ölçekler & & Cinsiyet & $\mathrm{n}$ & Ort. \pm Std. Sp. & $\mathrm{t}$ & $\mathrm{p}$ \\
\hline \multirow{4}{*}{$\begin{array}{c}\text { Sporda Saldırganlık ve Öfke } \\
\text { Ölçeği }\end{array}$} & \multirow[b]{2}{*}{ Saldırganlık } & Kadın & 56 & $2,83 \pm, 781$ & \multirow[b]{2}{*}{,711 } & \multirow[b]{2}{*}{,478 } \\
\hline & & Erkek & 126 & $2,73 \pm, 904$ & & \\
\hline & \multirow{2}{*}{ Öfke } & Kadın & 56 & $1,87 \pm, 713$ & \multirow{2}{*}{$-2,229$} & \multirow{2}{*}{,027 } \\
\hline & & Erkek & 126 & $2,12 \pm, 665$ & & \\
\hline \multirow{2}{*}{$\begin{array}{c}\text { Antrenörlerin Etik Dışı Davranış } \\
\text { Algısı ile İlgili Sporcu Algısı } \\
\text { Ölçeği }\end{array}$} & \multirow{2}{*}{ Etik Toplam Puan } & Kadın & 56 & $1,73 \pm, 800$ & \multirow{2}{*}{1,548} & \multirow{2}{*}{ 123 } \\
\hline & & Erkek & 126 & $1,55 \pm, 675$ & & \\
\hline
\end{tabular}

Tablo 4 de sporda saldırganlık ve öfke ölçeğinin saldırganlık alt boyutunda cinsiyete anlamlı farklılık görülmezken ( $p>0.05$ ), cinsiyete göre öfke alt boyutunda anlamlı farklılık tespit edilmiştir $(p<0.05)$. Antrenörlerin etik dışı davranış algısı ile ilgili sporcu algısı ölçeği toplam puanında ise cinsiyete göre anlamlı farklılık saptanmamıştır $(p>0.05)$.

Tablo 5. Branşa Göre Sporda Saldırganlık ve Öfke Ölçeği Ille Antrenörlerin Etik Dışı Davranış Algısı ile Illgili Sporcu Algısı Ölçeği t-Testi Analizi

\begin{tabular}{|c|c|c|c|c|c|c|}
\hline Ölçekler & & Branş & $\mathrm{n}$ & Ort. \pm Std. Sp & $\mathrm{t}$ & $\mathrm{p}$ \\
\hline \multirow{4}{*}{$\begin{array}{c}\text { Sporda Saldırganlık ve Öfke } \\
\text { Ölçeği }\end{array}$} & \multirow{2}{*}{ Saldırganlık } & Takım & 78 & $2,91 \pm, 884$ & \multirow{2}{*}{2,051} & \multirow{2}{*}{,040 } \\
\hline & & Bireysel & 104 & $265+840$ & & \\
\hline & \multirow{2}{*}{ Öfke } & Takım & 78 & $2.21+713$ & \multirow{2}{*}{2,924} & \multirow[b]{2}{*}{,003 } \\
\hline & & & & & & \\
\hline \multirow{3}{*}{$\begin{array}{c}\text { Antrenörlerin Etik Dışı Davranış } \\
\text { Algısı ile İlgili Sporcu Algısı } \\
\text { Ölçeği }\end{array}$} & \multirow{3}{*}{ Etik Toplam Puan } & & & & \multirow{3}{*}{2,109} & \multirow{3}{*}{,036 } \\
\hline & & $m$ & 18 & $1, / 3 \pm, / 52$ & & \\
\hline & & Bireysel & 104 & $1,51 \pm, 679$ & & \\
\hline
\end{tabular}


Güvendi B, Keskin B. (2020). Sporcuların Antrenörlerinden Algıladıkları Etik Dışı Davranış Algısına Göre Saldırganlık ve Öfke Davranışlarının İncelenmesi. Gaziantep Üniversitesi Spor Bilimleri Dergisi, 5(2), 134-145.

Tablo 5 de sporcuların branşlarına göre sporda saldırganlık ve öfke ölçeği alt boyutlarında ve antrenörlerin etik dışı davranış algısı ile ilgili sporcu algısı ölçeği toplam puanında anlamlı farklılık tespit edilmiştir $(p<0.05)$.

Tablo 6. Millilik Durumuna Göre Sporda Saldırganlık ve Öfke Ölçeği İle Antrenörlerin Etik Dışı Davranış Algısı ile İlgili Sporcu Algısı Ölçeği t-Testi Analizi

\begin{tabular}{|c|c|c|c|c|c|c|}
\hline Ölçekler & & Millilik & $\mathrm{n}$ & Ort. \pm Std. Sp. & $\mathrm{t}$ & $p$ \\
\hline & Saldırganlık & $\begin{array}{c}\text { Evet } \\
\text { Hayır } \\
\text { Evet }\end{array}$ & $\begin{array}{c}66 \\
116 \\
66\end{array}$ & $\begin{array}{l}2,61 \pm, 778 \\
2,85 \pm, 905 \\
1,92 \pm, 631\end{array}$ & $-1,812$ & 061 \\
\hline $\begin{array}{c}\text { Sporda Saldırganlık ve } \\
\text { Öfke Ölcceği }\end{array}$ & Öfke & Hayır & 116 & $2,11 \pm, 712$ & $-1,746$ & 073 \\
\hline $\begin{array}{c}\text { Antrenörlerin Etik Dışı } \\
\text { Davranış Algısı ile Illgili } \\
\text { Sporcu Algısı Ölçeği }\end{array}$ & $\begin{array}{l}\text { Etik Toplam } \\
\quad \text { Puan }\end{array}$ & $\begin{array}{l}\text { Evet } \\
\text { Hayır }\end{array}$ & $\begin{array}{c}66 \\
116\end{array}$ & $\begin{array}{l}1,60 \pm, 637 \\
1,61 \pm, 763\end{array}$ &,- 081 & 936 \\
\hline
\end{tabular}

Tablo 6 da yer alan analiz sonuçlarına bakıldığında sporcuların millilik durumuna göre sporda saldırganlık ve öfke ölçeği alt boyutlarında ve antrenörlerin etik dışı davranış algısı ile ilgili sporcu algısı ölçeği toplam puanında anlamlı farklıık görülmemiştir ( $p>0.05)$.

Tablo 7. Spor Yılına Göre Sporda Saldırganlık ve Öfke Ölçeği İle Antrenörlerin Etik Dışı Davranış Algısı ile İlgili Sporcu Algısı Ölçeği Anova Testi Analizi

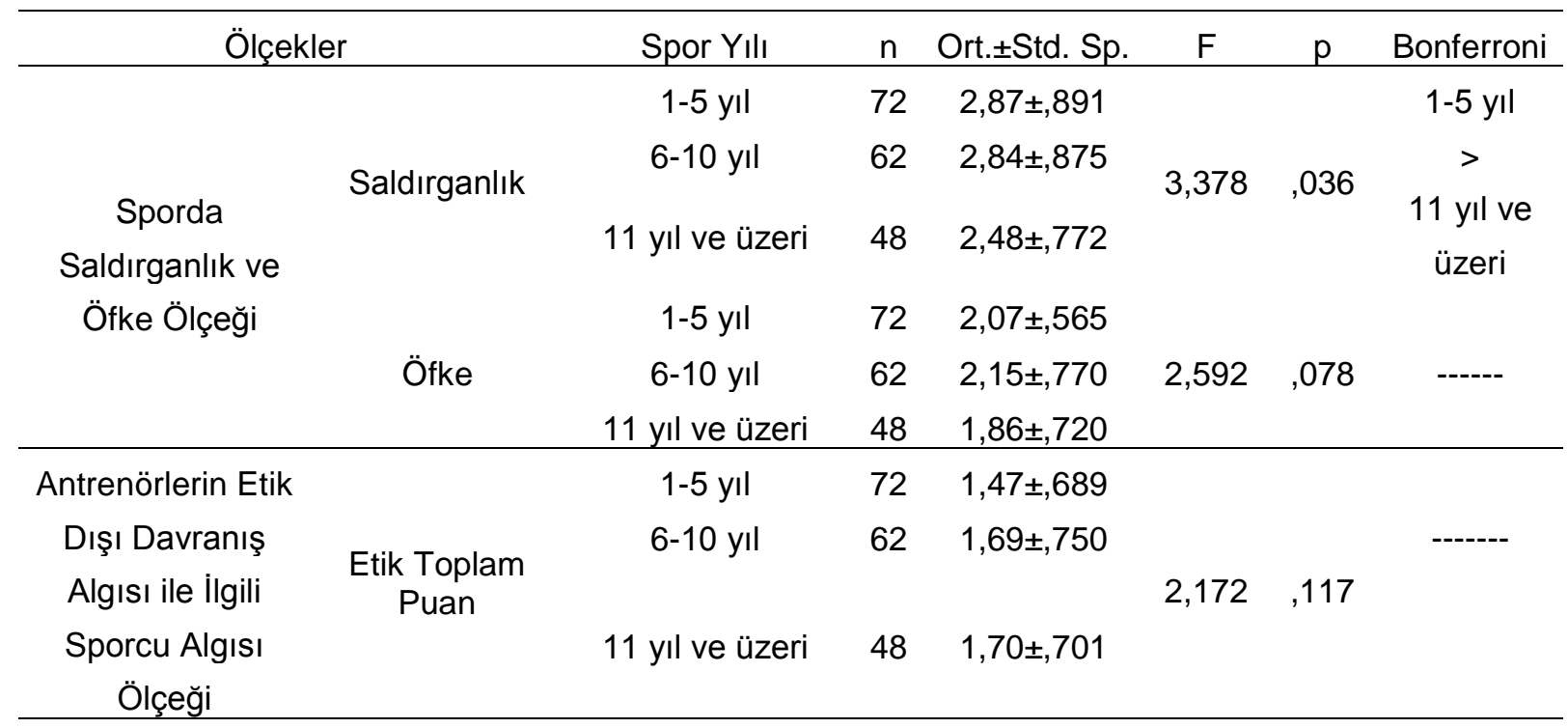

Tablo 7 de spor yılına göre sporda saldırganlık ve öfke ölçeğinin saldırganlık alt boyutunda anlamlı farklılık görülürken $(p<0.05)$, öfke alt boyutunda anlamlı farklılık görülmemiştir ( $p>0.05)$. Antrenörlerin etik dışı davranış algısı ile ilgili sporcu algısı ölçeği toplam puanında ise spor yılına göre anlamlı farklılık saptanmamışır ( $p>0.05)$. Farklılı̆ın hangi gruplar arasında olduğunu belirleyebilmek için örnek sayısındaki 
farklılıklara bakılmaksızın uygulanabilen çoklu karşılaştırma testlerinden Bonferroni testi kullanılmıştır.

Tablo 8. Yaşa Göre Sporda Saldırganlık ve Öfke Ölçeği İle Antrenörlerin Etik Dışı Davranış Algısı ile İlgili Sporcu Algısı Ölçeği t-Testi Analizi

\begin{tabular}{|c|c|c|c|c|c|c|}
\hline \multicolumn{2}{|c|}{ Ölçekler } & Yaş & $\mathrm{N}$ & Ort. \pm Std. Sp. & $\mathrm{t}$ & $\mathrm{p}$ \\
\hline \multirow{3}{*}{$\begin{array}{c}\text { Sporda } \\
\text { Saldırganlık ve } \\
\text { Öfke Ölçeği }\end{array}$} & \multirow[t]{2}{*}{ Saldırganlık } & $\begin{array}{c}15-17 \text { yaş } \\
18 \text { vas ve üzeri }\end{array}$ & $\begin{array}{c}109 \\
73\end{array}$ & $\begin{array}{l}2,76 \pm, 863 \\
2,76 \pm, 879\end{array}$ &,- 002 & \multirow[t]{2}{*}{,998 } \\
\hline & & 15-17 yas & 109 & $2,06 \pm, 631$ & & \\
\hline & Öfke & 18 yaş ve üzeri & 73 & $2,02 \pm, 769$ & ,345 & ,730 \\
\hline Antrenörlerin Etik & & 15-17 yaş & 109 & $1,50 \pm, 694$ & & \\
\hline $\begin{array}{l}\text { Dışı Davranış } \\
\text { Algısı ile İlgili } \\
\text { Sporcu Algısı }\end{array}$ & Etik toplam & 18 yaş ve üzeri & 73 & $1,75 \pm, 732$ & $-2,356$ & ,020 \\
\hline
\end{tabular}

Tablo 8 de yaşa göre sporda saldırganlık ve öfke ölçeği alt boyutlarında anlamlı farklılık görülmezken ( $p>0.05)$, antrenörlerin etik dışı davranış algısı ile ilgili sporcu algısı ölçeği toplam puanında anlamlı farklılık olduğu belirlenmiştir $(p<0.05)$.

\section{Tartışma ve Sonuç}

Bu çalışma sporcuların antrenörlerinden algıladıkları etik dışı davranış algısına göre saldırganlık ve öfke davranışları incelenerek bazı bağımsız değişkenlere göre farklılaşıp farklılaşmadığını araştırmak amacıyla yapılmıştır.

Elde edilen bulgulara göre, sporcuların sporda saldırganlık boyutunda kararsızlık yaşadıkları öfke boyutuna ve antrenörlerinden algıladıkları etik dışı davranış algısına katılmadıkları görülmüştür. Buna göre sporcular antrenörlerinden etik dışı davranış germediklerini belirtmişlerdir. Çalışmamızla benzer olarak, Certel, Alkış ve Gürpınar (2018) yaptıkları çalışmada antrenörlerin mesleki etik ilkelere ortalamanın üstünde uygun davrandıkları sonucuna ulaşmışlardır. Güvendi ve Işım (2019) tarafından yapılan çalışmada antrenörün etik dışı davranışları ile ilgili sporcu algısı ölçeğinden sporcuların antrenör-sporcu ilişkisi ve kişilik özellikleri boyutuna katılmadıkları, sportmenlik boyutundaki etik dışı davranışlara ise hiç katılmadıkları görülmüştür. Güvendi ve ark. (2016) antrenörlerin etik ilkelere uyma düzeylerinin sorumluluk ve saygı alt boyutları puanları orta düzeyin/ortalamanın üzerinde olduğu sonucuna ulaşmışlardır. Yapılan bu araştırma sonuçları çalışmamızı destekler niteliktedir. Çalışmamızdan farklı olarak Karakoç ve ark. (2011), sporcuların bakış açıları ile antrenörlerin etik dışı davranışlarını belirleyebilmek için yaptıkları 
çalışmada, sporcuların antrenörlerin etik dışı davranışları sergilemeleri ile ilgili düşüncelerine "Kesinlikle Katılıyorum" şeklinde cevap verdikleri görülmüştür.

Araştırmada yapılan korelasyon analizine göre sporda saldırganlık ve öfke ölçeği saldırganlık ve öfke alt boyutu ile antrenörlerin etik dışı davranış algısı ile ilgili sporcu algısı ölçeği ile toplam puanı arasında pozitif yönde ve düşük düzeyde anlamlı ilişki olduğu tespit edilmiştir. Buna göre sporcuların antrenörlerinden algıladıkları etik dışı davranış algısı arttıkça saldırganlık ve öfke düzeylerinin arttığı söylenebilir. Bu çalışma soncuna benzer olarak, Güvendi ve Işım (2019), tarafından yapılan takım sporcularının antrenörlerinden algıladıkları etik dışı davranışlara göre ahlaktan uzaklaşma düzeyleri başlıklı araştırma sonucunda sporcuların antrenörlerinden algıladıkları etik dışı davranış arttıkça ahlaktan uzaklaşma düzeylerinin de arttığını tespit etmişlerdir.

Diğer bir sonuca göre sporda saldırganlık ve öfke ölçeğinin saldırganlık alt boyutunda cinsiyete göre anlamlı farklılık görülmezken, öfke alt boyutunda da anlamlı farklar tespit edilmiştir. Elde edilen sonuçlarda erkeklerin öfke düzeylerinin kadın sporculardan daha yüksek olduğu belirlenmiştir. Çalışmamızdan farklı olarak Demir ve ark. (2017), yaptıkları çalışma sonucunda cinsiyet göre öfke ifade tarzları alt boyutlarında anlamlı farklılığın olmadığı görülmüştür. Certel ve Bahadır (2012)'ın çalışmalarında da kadın veya erkek sporcu olmanın sürekli öfke, içe ve dışa yönelik ve öfke kontrolünde anlamlı bir fark oluşturmadığı görülmüştür. Kafalı ve ark. (2017), nın yaptığı çalışmada ise sporcuların fiziksel ve sözel saldırganlık, öfke, düşmanlık, ve ölçeğin toplamında erkek katılımcıların bayan katılımcılara göre daha yüksek puanlara ve dolayısıyla daha saldırgan tutumlara sahip olduğu sonucuna ulaşılmıştır. Ayrıca çalışmada cinsiyete göre antrenörlerin etik dışı davranış algısı ile ilgili sporcu algısı ölçeği toplam puanında anlamlı farklılık saptanamamıştır. Güven ve Öncü (2012) sporcuların antrenörlerinden algıladıkları etik dışı davranış algıları ile cinsiyet değişkeni arasında anlamlı bir farklılık olmadığı sonucuna ulaşmıştır. Caz (2019) çalışmasının sonucunda kadın ve erkek sporcuların antrenörlerin etik dışı davranışları ile ilgili sporcuların algısında herhangi bir farklılık gözlenmemiştir. Certel, Alkış ve Gürpınar (2018), antrenörlerin mesleki etik ilkelere uyma düzeylerinin sporcuların cinsiyetlerine farklılaşmadığını ifade etmişlerdir. Benzer olarak Güvendi ve Işım (2019) antrenörün etik dışı davranışları ile ilgili sporcu algısı ölçeğinde cinsiyete göre anlamlı farklılık olmadığı sonucuna ulaşmışladır. 
Güvendi B, Keskin B. (2020). Sporcuların Antrenörlerinden Algıladıkları Etik Dışı Davranış Algısına Göre Saldırganlık ve Öfke Davranışlarının İncelenmesi. Gaziantep Üniversitesi Spor Bilimleri Dergisi, 5(2), 134-145.

Bu çalışmada sporcuların branşlarına göre sporda saldırganlık ve öfke ölçeği alt boyutlarında ve antrenörlerin etik dışı davranış algısı ile ilgili sporcu algısı ölçeği toplam puanında takım anlamlı farklılık tespit edilmiştir. Bu sonuca göre takım sporcuların antrenörlerinden algıladıkları etik dışı davranış algısı ile saldırganlık ve öfke boyutları ortalama puanlarının bireysel spor yapanlara göre daha yüksek olduğu görülmektedir. Bu çalışmadan farklı olarak Caz (2019) bireysel veya takım sporcuları arasında antrenörlerin etik dışı davranışları hakkındaki düşünce düzeyinde farklılık yaratmadığını belirtmiştir. Certel, Alkış ve Gürpınar (2018) antrenörlerin mesleki etik ilkelere uyma düzeylerinin bireysel, takım ve mücadele sporları yapma durumlarına göre farklılaşmadığını belirtmiştir. Tutkun ve ark. (2010) bireysel spor yapanların yıkıcı ve edilgen saldırganlık puanlarının takım sporu yapanlara göre istatistiksel olarak anlamlı daha yüksek olduğu sonucuna ulaşmışlardır. Kafalı ve ark. (2017)'nın yaptıkları çalışma da ise katılımcıların fiziksel saldırganlık alt boyutunda düşmanlık alt boyutunda ve ölçeğin toplamında bireysel sporlarla uğraşan sporcuların takım sporcularının puanlarına göre daha yüksek puanlara ve dolayısıyla daha saldırgan tutumlara sahip olduğu görülürken öfke ve sözel saldırganlık alt boyutlarında ise anlamlı farklılık tespit edilmemiştir.

Çalışmamızda sporcuların millilik durumlarına göre anlamlı farklılık belirlenmemiştir. Çalışmamızla benzer olarak Caz (2019), sporcuların millilik düzeyinin, antrenörlerin etik dışı davranışları hakkındaki düşünce düzeyinde farklılık yaratmadığı sonucuna ulaşmıştır. Güvendi ve Işım (2019'ın çalışmasında sporcuların millilik durumlarına göre antrenörün etik dışı davranışları ile ilgili sporcu algısı ölçeğinde anlamlı farklılığa rastlanılmamıştır. Çalışmamızdan farklı olarak Güven ve Öncü (2012) milli olmayan sporcuların antrenörlerinin etik olmayan davranışları ile ilgili algılarının milli olan sporculara göre daha olumsuz olduğu görülmüştür.

Yaşa göre bakıldığında ise saldırganlık ve öfke alt boyutlarında anlamlı farklılık görülmezken 18 yaş ve üzerindeki sporcuların antrenörlerinden algıladıkları etik dışı davranış algısı 15-17 yaş arasındaki sporculara göre daha fazladır. Benzer olarak Güvendi ve Işım (2019)' da yaptıkları çalışmada, yaşa göre antrenörün etik dışı davranışları ile ilgili sporcu algısı ölçeğinin tüm alt boyutlarında anlamlı farklılık olduğunu ve 19-21 yaş ve 23 yaş ve üzeri sporcuların antrenörlerinden algıladıkları etik dışı davranış ortalama puanlarının 16-18 yaşında olan sporculara göre daha yüksek olduğunu tespit edilmiştir. Buna göre yaş arttıkça antrenöründen algılanan etik dışı davranış algısının da arttığı söylenebilir. Çalışmamızla benzer olarak, Demir 
ve ark. (2017)' da sporcular ile yaptığı çalışmada yaş değişkeni ile öfke alt boyutları arasında anlamlı farkın olmadığını ifade etmişlerdir. Saldırganlık ile ilgili yapılmış çalışmalara bakıldığında ise Ersoy, Tazegül, ve Sancaklı (2012) güreşçilerin yaşlarının saldırganlık üzerinde bir etkisinin olmadığı görülmüştür. Kafalı ve ark. (2017), ise sporcuların saldırganlık ve öfke düzeylerinin yaşa göre değişmediğini ifade etmişlerdir. Literatür bulguları çalışma sonuçlarımızı destekler niteliktedir.

Araştırma bulgularında spor yılına göre sporda saldırganlık ve öfke ölçeğinin saldırganlık alt boyutunda anlamlı farklılık görülürken, öfke alt boyutunda ise anlamlı farklıık tespit edilmemiştir. Buna göre, spor yılı düşük olan sporcuların saldırganlık puanlarının spor yılı yüksek olan diğer bir ifade ile tecrübeli sporculara göre daha yüksek olduğu görülmüştür. Çalışmada başka bir bulgu olan antrenörlerin etik dışı davranış algısı ile ilgili sporcu algısı ölçeği toplam puanında ise spor yılına göre anlamlı farklılık saptanmamışıı. Bu çalışma ile benzer olarak Caz (2019) amatör ve profesyonel olarak sınıflandırımış sporculuk düzeyinin, antrenörlerin etik dışı davranışları hakkındaki düşünce düzeyinde farklılık yaratmadığını belirtmiştir.

Sonuç olarak sporcuların algıladıkları etik dışı davranış algısı artıkça saldırganlık eylemlerini ve öfke hislerini artırmaktadır. Bu durum özellikle antrenörlerin müsabakaya kazanma odaklı yaklaşmaları ile sporcularını bu tarz eylemlerle motive etmelerinden kaynaklanabileceği düşünülmektedir. Erkek sporcuların yapıları gereği daha fazla öfkelendiği söylenebilir. Çalışmamıza katılan takım sporcularının çoğunluğunun futbol ve basketbol oyuncuları olduğu düşünüldüğünde bu branşların daha fazla kazanma odaklı olması ve kazanmanın sadece birey için değil takım ve yöneticiler içinde büyük anlam ifade etmesinden dolayı antrenörler, gerek yönetimin talepleri ya da kendi kişisel hırsları yüzünden kazanmak adına etik olmayan davranışlar sergileyebilmekte ve sporcularını da bu doğrultuda etkileyebilmektedir. $\mathrm{Bu}$ durumda sporcuların öfke hislerinin yoğunlaşmasına ve saldırganlık eylemlerini sergilemelerine yol açmaktadır diyebiliriz. Spora yeni başlamış sporcuların tecrübesiz olmalarından dolayı davranışlarını kontrol etmekte zorlandıkları söylenebilir. Son olarak yaşça daha büyük sporcuların spor ortamından edindikleri bilgi birikimi ile birlikte antrenörlerin isteklerinin ya da taleplerinin sonucunun ne ile sonuçlanabileceğinin farkında olduklarını ve yorumlayabildiklerini söyleyebiliriz. Bu bağlamda federasyonların kulüplere zorunlu olacak şekilde antrenörlerin uymaları gereken etik ilkelerin seminerler düzenlenerek 
sporculara duyurulmasını ile sporcuların farkındalıklarının artıııması sağlanarak sporda görülen etik dışı davranışların azalabileceği düşünülmektedir.

\section{Kaynakça}

Albrecht, R. (2003). Positive Cooaching, Motivation and Communication. Research Study For The Study of Young Sports, Michigan State University. (https://slideplayer.com/slide/5177545/).

Caz, Ç. (2019). Antrenörlerin Sergilemiş Olduğu Etik Dışı Davranışların Sporcu Gözüyle Değerlendirilmesi. Gelecek Vizyonlar Dergisi, 3(1), 20-25.

Certel, Z.,\&Bahadır, Z. (2012). Takım Sporu Yapan Sporcularda Benlik Saygısı ve Sürekli Öfke ve Öfke İfade Tarz İlişkisinin İncelenmesi. Selçuk Üniversitesi Beden Eğitimi veSpor Bilim Dergisi, 14(2), 157-164.

Certel, Z., Alkış, A., \& Gürpınar, B. (2018). Antrenörlerin Mesleki Etik İlkelere Uyma Düzeylerinin Antrenör ve Sporcu Gözüyle Değerlendirilmesi. Mediterranea Journal Of Humanities, 8(2), 223-231.

Demir, H., Sezan, T., Demirel, H., Yalçın, Y. G.,\&Altın, M. (2017). Sporcuların Öfke Ifade Tarzları. Mehmet Akif Ersoy Üniversitesi Sosyal Bilimler Enstitüsü Dergisi, 9(19), 408-414.

Doğan, O. (2005). Spor Psikolojisi. Nobel: Adana.

Dolaşır, S. (2006). Antrenörlük Etiği ve İlkeleri, Gazi Kitapevi, Baran Ofset: Ankara.

Dolaşır-Tuncel, S.,\&Büyüköztürk, Ş. (2009). Antrenörlerin Mesleki Etik İlkeleri Nelerdir? Nasıl Ölçülür? Ölçek Geliştirme: Ölçeğin Geçerlik ve Güvenirliği. Spormetre Beden Eğitimi ve Spor Bilimleri Dergisi, 7(4), 159-168.

Ersoy, A.,Tazegül, Ü.,\& Sancaklı, H. (2012). Güreşçilerin Saldırganlık Düzeylerinin Sosyo Demografik Açıdan İncelenmesi (Ankara Örneği). Uluslararası İnsan Bilimleri Dergisi, 9(1), 385-397.

Guvendi, B.,\&lsim, A. T. (2019). Moral Disengagement Level of Team Athletes Depending on Unethical Behaviors They Perceived from Their Coaches. Journal of Educationand Learning, 8(4), 83-92.

Gürbüz, B., Kural, S.,\& Özbek, O. (2019). Sporda Saldırganlık ve Öfke Ölçeği: Geçerlik ve Güvenirlik Çalışması. Sportif Bakış: Spor ve Eğitim Bilimleri Dergisi, 6(2), 206-217. 
Güven, Ö.,\& Öncü, E. (2012). Antrenörlerin Etik Dışı Davranışları ile İlgili Sporcu Algısı Ölçeğinin Geliştirilmesi. Spormetre Beden Eğitimi ve Spor Bilimleri Dergisi, 10(2), 67-75.

Güvendi, B., Türksoy, A., Keskin, N., Altıncı, E.E.,\&Şahin, S. (2016). Antrenörlerin Mesleki Etik İlkelere Uyma Düzeyleri ile Kişilik Özellikleri Arasındaki İlişkinin İncelenmesi. Uluslararası Hakemli Psikiyatri ve Psikoloji Araştırmaları Dergisi Sayı: 7, 43-61.

Kafalı, S., Hünkar, İ., Keçeci, O.,\& Demiray, E. (2017). Bireysel Spor ve Takım Sporu Yapan Sporcuların Saldırganlık Düzeylerinin Araştırıması. Journal of International Social Research, 10(50), 386-390.

Karagün, E.,\&Çağlayan, Ç. (2014). Sporcuların Şiddete Maruz Kalma Durumları ile Öfke Düzeylerinin Değerlendirilmesi. Kocaeli Üniversitesi Sosyal Bilimler Dergisi, Sayı:28, 113-127.

Karakoç, Ö., Yüksek, S., Aydın, A.D., Karakoç, B., Yetiş, Ü.,\&Baydil, B. (2011). Milli takım düzeyindeki erkek judocuların kulüp antrenörlerinde gözlemledikleri etik dışı davranışlar. Kastamonu Eğitim Dergisi, 19(1), 321-332.

Karasar, N. (2012). Bilimsel Araştırma Yöntemi. Nobel: Ankara.

Tiryaki, Ş. (2000). Spor Psikolojisi. Eylül: Ankara.

Tuna, D.(2012). Çözüm Odakıı Kısa Süreli Yaklaşıma Dayalı Öfke Kontrolü Eğitim Programının Lise Öğrencilerinin Öfke Kontrolü ve İletişim Becerileri Düzeylerine Etkisi. Yüksek Lisans Tezi, Dokuz Eylül Üniversitesi Eğitim Bilimleri Enstitüsü, İzmir.

Tutkun, E., Güner, B. Ç., Ağaoğlu, S. A., \& Soslu, R. (2010). Takım Sporları ve Bireysel Sporlar Yapan Sporcuların Saldırganlık Düzeylerinin Değerlendirilmesi. Spor ve Performans Araştırmaları Dergisi, 1(1), 23-29. 